OCTOBER 2020

\title{
U.S. Semiconductor Exports to China: Current Policies and Trends CSET Issue Brief
}

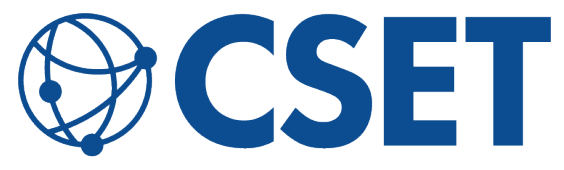

CENTER for SECURITY and AUTHOR EMERGING TECHNOLOGY

\author{
Saif M. Khan
}




\section{Table of Contents}

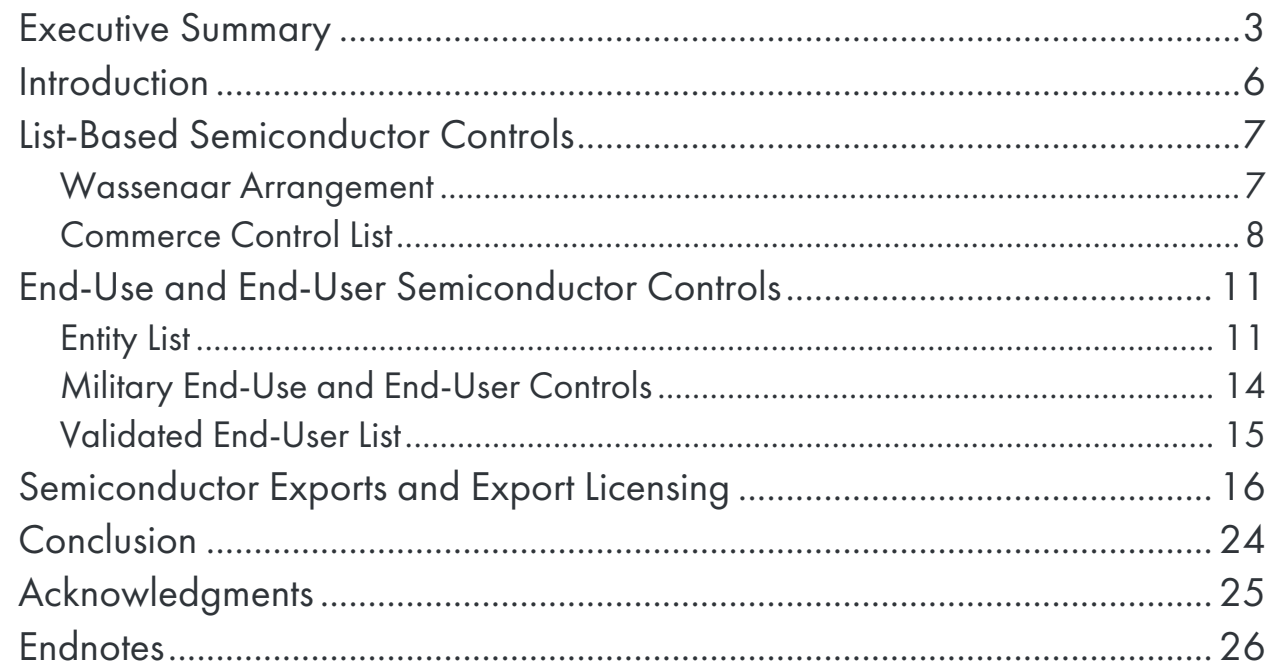




\section{Executive Summary}

The United States has long used export controls to prevent the proliferation of advanced semiconductors and the inputs necessary to produce them. Semiconductors underpin virtually all aspects of economic and technological development, therefore impacting national and international security. The United States and a small number of democratic allies are the sole producers of advanced semiconductors and many key inputs necessary to manufacture them, creating the option of using export controls as nonproliferation tools. In particular, the United States has recently tightened semiconductor export controls on China, given Beijing's efforts to build a domestic semiconductor industry to answer the demands of "Made in China 2025" and address overreliance of Chinese high-technology industries on imported semiconductors.

Currently, the United States applies multiple types of semiconductor export controls on China. "List-based controls" is a term of art that refers to a list of specific technologies whose export is controlled. "End-use and end-user controls" refer to lists of prohibited end-uses for exported technologies and end-users that cannot receive exports. To export any controlled items, exporters must obtain export licenses- which can be denied by licensing officers.

List-based controls cover exports of various types of semiconductor manufacturing equipment (SME), chips, materials, software, and technical data to all Chinese entities (public and private). Export license decisions are made on a case-by-case basis, historically resulting mostly in approvals.

- Among SME, these controls cover some types of lithography, deposition, ion implanting, testing, and wafer handling tools, but not etching, process control, assembly, and wafer manufacturing tools.

- Among high-end semiconductors, these controls cover fieldprogrammable gate arrays (FPGAs), partly cover central processing units (CPUs), and do not cover graphics processing units (GPUs); it remains unclear whether they cover application-specific integrated circuits (ASICs) customized for artificial intelligence. 
- Among materials, these controls cover certain types of masks, resists, consumable gases, wafers, and materials that become wafers and chips.

- Among software, these controls cover software used with or to help produce SME, but not electronic design automation (EDA) software used to design chips.

- Technical data associated with the above technologies is also controlled.

- These controls also require U.S. employers to apply for "deemed export licenses" for Chinese nationals who would access controlled technical data or source code in the United States during their employment.

On top of the list-based controls broadly applied to China, end-use and end-user controls apply additional, more stringent controls on certain Chinese end-uses and end-users-with wider technology coverage and presumption of denial of export licenses.

- Recent "entity listings" cover certain public and private semiconductor-related entities, including chip designers and endusers (like Huawei), various Chinese supercomputing entities, and Chinese chipmakers (like Fujian Jinhua). These controls typically cover all semiconductor technologies.

- Other controls target the Chinese military and civilian Chinese entities supporting the military or engaging in military end-uses, such as Semiconductor Manufacturing International Corporation (SMIC). These controls cover many types of chips (including CPUs, FPGAs, and AI ASICs, but probably not GPUs) and a wide variety of SME.

- However, the United States allows some Chinese semiconductor firms-which follow certain requirements as Validated End-Users (VEUs)-to import otherwise controlled technologies under a general license.

U.S. semiconductor exports to China have increased in recent years because of permissive export licensing policy and declining technology coverage of export controls, but these trends may be changing. 
- In particular, exports of SME more than doubled from 2014 to 2019, especially owing to fewer U.S. SME being controlled. Exports of semiconductors also increased in this period, although exports of materials declined.

- However, the United States has recently been tightening semiconductor export controls with stricter licensing policies (including for deemed exports for Chinese nationals), stricter controls on major Chinese entities like Huawei, and expanded military end-use and end-user controls to cover a wider range of Chinese end-uses and end-users, such as SMIC. 


\section{Introduction}

Semiconductors are essential to the advanced technology powering economic, technological, and military competitiveness. ${ }^{.}$Therefore, policies relating to semiconductors-and the inputs needed to make them ${ }^{2}$ - have major impacts on national and international security.

The United States is now tightening export controls on the inputs China needs to build its semiconductor industry and on the finished semiconductors Chinese high-technology firms and the military currently rely on. This report places these changes in broader context, mapping the current state of U.S. semiconductor export control policy and how policy changes have impacted U.S. semiconductor exports to China in recent years.

The report begins with an overview of the types of semiconductor export controls the United States applies to China. First, the United States uses "listbased controls" on exports of specific semiconductor technologies to all Chinese entities, though it approves most export licenses. These technologies include inputs to semiconductor production-such as semiconductor manufacturing equipment (SME), materials, software, and intellectual property-and the finished semiconductors themselves. The list-based controls also regulate the acquisition of this intellectual property and software by Chinese nationals in the United States. In addition to list-based controls, the United States uses "end-use and end-user controls" on exports for a wider set of technologies, and typically denies export licenses for certain military enduses and specific end-users. These end-users include Chinese semiconductor firms and semiconductor consumers, such as high-technology Chinese firms, the Chinese military, and civilian entities supporting the military.

The report closes with an analysis of the impacts of U.S. semiconductor export policies on actual U.S. semiconductor exports. It shows that, by 2018 , export controls covered fewer semiconductor technologies than before, causing an increase in exports to China, particularly of SME and chips. However, these trends may be reversing, as the United States now applies stricter export licensing policies and expanded end-use and end-user controls on the Chinese military, civilian entities supporting the military, and other major Chinese organizations. 


\section{List-Based Semiconductor Controls}

List-based controls encompass specific technologies whose export is controlled. The United States maintains a list of controlled technologies called the U.S. Commerce Control List, covering a wide range of semiconductor technologies. The foundation for the U.S. Commerce Control List and allied list-based controls is the internationally agreed upon list produced by the Wassenaar Arrangement. Each country that is a party to the Wassenaar Arrangement bases its export controls on this list.

\section{Wassenaar Arrangement}

The Wassenaar Arrangement, a voluntary association with 42 member states, produces a list of dual use technologies and munitions on which signatories should impose export controls. The list specifies more than 150 semiconductor end-products and more than 20 types of SME. ${ }^{3}$ Member states include those at the leading edge of semiconductor and semiconductor manufacturing equipment production-namely, the United States, the Netherlands, ${ }^{4}$ Japan, ${ }^{5}$ Germany, ${ }^{6}$ and South Korea. Russia is also a member. Each of these states have harmonized their export regulations on semiconductor related technologies with the Wassenaar Arrangement's list. Notably, Taiwan cannot join the Wassenaar Arrangement because of its legal status. However, Taiwan's Bureau of Foreign Trade maintains an export control list based on the Wassenaar Arrangement's list. ${ }^{7}$

The control lists divide technologies into five product groups: two covering physical commodities, and three others covering materials, software, and technical data. ${ }^{8}$ Export controls on technical data and software are associated with the concept of "deemed exports." A deemed export is when a foreign national (one without a U.S. green card or U.S. citizenship) acquires controlled technical data or source code, even if they are in the United States at the time. This acquisition is treated like a normal export. Accordingly, export controls can prevent foreign nationals from working in U.S. industries that otherwise risk imparting controlled technical data or source code. 


\section{Commerce Control List}

The U.S. Commerce Control List, administered by the Commerce Department's Bureau of Industry and Security (BIS), generally includes the same export controls as the Wassenaar Arrangement, including for semiconductors. The difference is that the U.S. list has additional sections on military-grade versions of the listed technologies and an expanded set of controls for five countries designated as state sponsors of terrorism (North Korea, Cuba, Iran, Sudan, and Syria). A separate U.S. control regime, the International Traffic in Arms Regulation, additionally lists a small number of other military-grade semiconductor export controls. ${ }^{9}$

Table 1 summarizes the U.S. Commerce Control List's export controls on China for certain high-value parts of the semiconductor supply chain. ${ }^{10} \mathrm{To}$ export these items to any Chinese entity (public or private), exporters must obtain export licenses, which licensing officers grant on a case-by-case basis. " As required by the Export Control Reform Act of 2018, BIS is currently reviewing whether to amend the export control regulations to make them more restrictive for various emerging and foundational technologies, including semiconductor manufacturing equipment, $\mathrm{Al}$ chipsets, quantum computing, microprocessor technology such as systems-on-chips (SoCs) or stacked memory on chip, and advanced computing technology such as memory-centric logic. ${ }^{12}$ 
Table 1: Key semiconductor items on the Commerce Control List

\begin{tabular}{|c|c|c|c|}
\hline Category & Item & Export controls applied to China? ${ }^{13}$ & $\begin{array}{l}\text { Related technical } \\
\text { data controlled for } \\
\text { China? }\end{array}$ \\
\hline \multirow[t]{12}{*}{$\mathrm{SME}^{14}$} & Wafer manufacturing & No & No \\
\hline & Wafer handling ${ }^{15}$ & Yes & Yes \\
\hline & Ion implanters ${ }^{16}$ & $\begin{array}{l}\text { Yes (high-current ion implanters for certain } \\
\text { dopants) }\end{array}$ & Yes \\
\hline & Chemical mechanical planarization & No & No \\
\hline & Deposition $^{17}$ & $\begin{array}{l}\text { Yes (some types of chemical \& physical } \\
\text { vapor deposition for certain materials) }\end{array}$ & Yes \\
\hline & $\begin{array}{l}\text { Photolithography scanners \& } \\
\text { steppers }^{18}\end{array}$ & Yes (extreme ultraviolet (EUV) scanners) & Yes \\
\hline & Imprint lithography ${ }^{19}$ & Yes & Yes \\
\hline & $\begin{array}{l}\text { Electron-beam lithography (for chip } \\
\text { and mask-making) and laser and } \\
\text { ion-beam lithography (for mask- } \\
\text { making) }{ }^{20}\end{array}$ & Yes & Yes \\
\hline & Etching & No & No \\
\hline & Process control & No & No \\
\hline & Testing $^{21}$ & $\begin{array}{l}\text { Yes (for microwave chips and discrete } \\
\text { transistors) }\end{array}$ & No \\
\hline & Assembly and packaging & No & No \\
\hline \multirow[t]{2}{*}{ Software } & Software to produce or use $\mathrm{SME}^{22}$ & Yes & No \\
\hline & EDA software ${ }^{23}$ & No & No \\
\hline \multirow[t]{4}{*}{ Chips $^{24}$} & $\mathrm{CPUs}^{25}$ & No & Yes \\
\hline & GPUs $^{26}$ & No & No \\
\hline & $\mathrm{FPGAs}^{27}$ & Yes & Yes \\
\hline & $\mathrm{Al} \mathrm{ASICs}{ }^{28}$ & Unclear & Unclear \\
\hline \multirow[t]{6}{*}{ Materials } & Wafers $^{29}$ & Yes (certain compound semiconductors) & Yes \\
\hline & $\begin{array}{l}\text { Boules and ingots (pre-wafer } \\
\text { material) }\end{array}$ & Yes (certain compound semiconductors) & Yes \\
\hline & Masks $^{31}$ & $\begin{array}{l}\text { Yes (EUV masks; other masks for controlled } \\
\text { chips e.g. FPGAs) }\end{array}$ & Yes \\
\hline & Resists $^{32}$ & $\begin{array}{l}\text { Yes (for photolithography, positive resists for } \\
<193 \mathrm{~nm} \text {, all resists for < } 15 \mathrm{~nm} \text {; and for e- } \\
\text { beam and imprint lithography) }\end{array}$ & Yes \\
\hline & Etching gas (hydrogen fluoride) ${ }^{33}$ & Yes & Yes \\
\hline & Dopants ${ }^{34}$ & Yes & Yes \\
\hline
\end{tabular}


In addition to controlling direct exports from the United States to another country, these export controls can apply to an item "re-exported" from one foreign country (e.g., Japan, South Korea, Germany) to another (e.g. China) in two ways.

First, under the de minimis rule, U.S. export controls apply if an item includes a threshold percentage of U.S.-origin content controlled in the receiving foreign country. ${ }^{35}$ For example, if the receiving foreign country is China, the de minimis threshold is zero percent for controlled chips ${ }^{36}$ with the exception of 25 percent for controlled memory chips. For uncontrolled chips, the threshold is also 25 percent. Therefore, the de minimis rule covers a chip fabricated outside the United States if U.S.-origin materials contribute to the applicable percentage in value of the chip. Notably, U.S.-origin intellectual property does not count toward the de minimis rule when incorporated into a tangible item. ${ }^{37}$ Therefore, when U.S. fabless chip designer Advanced Micro Devices sends controlled U.S.-origin CPU design IP to Taiwan for chip fabrication, U.S. controls do not apply to exports of these chips from Taiwan to China regardless of the percentage of controlled U.S.-origin CPU design IP the fabricated CPU includes.

Second, under the foreign-produced direct product rule, export controls apply if certain highly controlled U.S.-origin content is used to produce the item and if that content is controlled in the receiving foreign country. For example, the foreign-produced direct product rule may cover chips manufactured abroad using highly controlled U.S.-origin SME. ${ }^{38}$

Both rules are triggered if the receiving foreign country is China and the content is listed in the U.S. Commerce Control List with a "national security" designation, as is the case for nearly all controlled items listed in Table 1. ${ }^{39}$ 


\section{End-Use and End-User Semiconductor Controls}

In addition to the previously discussed list-based controls, end-use and enduser controls create a stricter layer of controls on certain Chinese end-uses and end-users. Specifically, the United States applies end-user controls on organizations and persons to whom exports of specified items are highly controlled, even if not by list-based controls. It also controls military end-uses of otherwise uncontrolled items, even if private actors perform such end-uses. Various agencies apply end-user lists: the BIS's Entity List, ${ }^{40}$ Denied Persons List, ${ }^{41}$ and military end-user controls; ${ }^{42}$ the State Department's list of Debarred Parties; ${ }^{43}$ and the Treasury Department's list of specially designated nationals. ${ }^{44}$ BIS also maintains a Validated End-User List, including entities subject to less stringent licensing requirements than others. This section focuses on the Entity List, the VEU List, and military end-use and end-user controls, which affect several large consumers of U.S. semiconductor technologies.

\section{Entity List}

BIS lists roughly 180 Chinese entities on its Entity List, which are subject to more stringent controls on top of those imposed by the Commerce Control List. It additionally lists foreign affiliates of these entities. ${ }^{45}$ BIS may choose to require an export license for exports to entities on the Entity List for either a subset or all items under BIS's jurisdiction. ${ }^{46} \mathrm{BIS}$ 's jurisdiction includes any U.S.-origin commodities, software, or related technical data-which includes virtually all semiconductor-related exports-with some exceptions for items normally in the public domain. ${ }^{47}$ Although these entity listings prevent direct U.S. exports to China, they do not expand the scope of re-export rules (the de minimis rule and the foreign-produced direct product rule) applied to entities on the Entity List. Several firms and their domestic and foreign affiliates on the Entity List have particular relevance to the U.S. semiconductor industry. Six of these groups are included in Table 2. For each of them, export controls apply to all items under BIS's jurisdiction: all chips, SME, EDA software, materials, and related intellectual property. The following discussion also provides more detail on the Fujian Jinhua, Huawei, Sugon, and National Supercomputing Center cases, which had significant impacts on the U.S. semiconductor industry. 
Table 2: Entity listings significantly impacting the semiconductor industry

\begin{tabular}{|l|l|l|l|}
\hline Firm and its affiliates & License review policy & $\begin{array}{l}\text { Industry } \\
\text { segment }\end{array}$ & $\begin{array}{l}\text { Reason for entity } \\
\text { listing }\end{array}$ \\
\hline Fujian Jinhua Integrated Circuit & Presumption of denial & $\begin{array}{l}\text { Memory chip } \\
\text { maker }\end{array}$ & $\begin{array}{l}\text { Trade secret theft } \\
\text { from U.S. memory } \\
\text { chip maker Micron }\end{array}$ \\
\hline Huawei Technologies & Presumption of denial & Chip end-users & $\begin{array}{l}\text { National security } \\
\text { concerns }\end{array}$ \\
\hline Sugon & Presumption of denial & $\begin{array}{l}\text { CPU and } \\
\text { supercomputer } \\
\text { developer }\end{array}$ & $\begin{array}{l}\text { National security } \\
\text { concerns }\end{array}$ \\
\hline $\begin{array}{l}\text { China Electronics Technology } \\
\text { Group \& Chengdu GaStone } \\
\text { Technology }\end{array}$ & Presumption of denial & $\begin{array}{l}\text { Chip design and } \\
\text { fabrication }\end{array}$ & $\begin{array}{l}\text { Illicit procurement } \\
\text { of technologies for } \\
\text { military end-uses }\end{array}$ \\
\hline $\begin{array}{l}\text { National Supercomputing Centers } \\
\text { Firms assisting Chinese } \\
\text { government's surveillance of } \\
\text { Uyghurs }{ }^{49}\end{array}$ & $\begin{array}{l}\text { Case-by-case basis } \\
\text { specified items, presumption } \\
\text { of denial for all others }\end{array}$ & Chip end-users & $\begin{array}{l}\text { National security } \\
\text { concerns over } \\
\text { military uses of } \\
\text { supercomputers }\end{array}$ \\
\hline
\end{tabular}

Fujian Jinhua. In 2018, BIS placed Chinese memory chip maker Fujian Jinhua on the Entity List with presumptive denial of export licenses in response to its alleged theft of trade secrets worth billions of dollars from U.S. memory chip maker Micron Technology..$^{50}$ Fujian Jinhua had just built a $\$ 6$ billion plant and was receiving and bringing online SME. The day the United States announced the export ban-which denied Fujian Jinhua access to U.S.-origin SME and materials, among other items-staff from U.S. SME firm Applied Materials "packed up and left," and engineers from U.S. SME firms KLATencor and Lam Research and Dutch SME firm ASML quickly followed suit. ${ }^{51}$ ASML may have obeyed the export ban because it recognized that its photolithography equipment had little value for chip fabrication without complementary SME including deposition, etch, and process control equipment. Anonymous executives of multiple Japanese SME firms including Tokyo Electron said they would not sell to Chinese firms on the U.S. Entity List 
out of "fairness" and to prevent U.S. backlash to Japanese attempts to take market share from U.S. competitors. ${ }^{52}$ In 2019 , Fujian Jinhua halted operations. $^{53}$

Huawei. In 2019, BIS placed Huawei on the Entity List with presumptive denial of export licenses. ${ }^{54}$ BIS issued a temporary general license for a narrow set of exports, re-exports, and in-country transfers to Huawei for U.S. telecom carriers with Huawei equipment to maintain their systems. ${ }^{55}$ This license expired in August 2020. ${ }^{56}$ Several U.S. chip firms stopped supplying chips to Huawei. Other U.S. and foreign chip firms work around the ban by manufacturing chips abroad. ${ }^{57}$ U.S. electronic design automation (EDA) software firms are more clearly subject to the export ban, as they directly export to China. Huawei's subsidiary HiSilicon self-designs chips that meet one-fifth of Huawei's chip demand. ${ }^{58}$ Synopsys, a leading U.S. EDA software firm, confirmed it stopped providing software updates and IP to Huawei, preventing Huawei from developing the most advanced designs. A representative of China's top EDA software firm Empyrean Software said, "[w]e would definitely want to help Huawei if we could, but we really do not have that capability[.] It would be like we sold cars, but Huawei came in and asked us to build airplanes or even rockets for them." ${ }^{59}$ Additionally, the entity listing-because it did not expand the scope of controlled re-exports-left Huawei the option to obtain chips manufactured by fabs (such as TSMC) outside the United States. To close this loophole, BIS added more stringent reexport controls specific to Huawei in 2020, complementing the existing reexport controls broadly applicable to exports to China. Specifically, the new re-export rules prevent Huawei from obtaining chips manufactured by any fabs in the world using U.S. SME. ${ }^{60}$ Given U.S.-China trade tensions, Huawei had been stockpiling U.S. components for a year before the export ban, ${ }^{61}$ and its phones now include fewer U.S. components. ${ }^{62}$ But in light of the new re-export controls, Huawei may run out of chips.

Sugon. In 2016, Chinese supercomputer developer Sugon partnered with U.S. chip firm Advanced Micro Devices to design chips using AMD's x86 CPU design. After AMD faced sharp revenue declines in 2015 to 2016 , the deal brought a much-needed infusion of cash and the promise of ongoing licensing revenues for chips developed under the joint venture. ${ }^{63}$ In 2019 , BIS placed Sugon and related entities on the Entity List with presumptive denial of export licenses, forcing AMD to withdraw from the joint venture. ${ }^{64}$ It is unclear whether Sugon can continue to fabricate the current version of the chip or design new versions without AMD's technical help. Some claim this joint 
venture gave China know-how and a foothold in the $\times 86$ market, but AMD claims the licensed designs were not state of the art. ${ }^{65}$ Others suggest AMD shared little IP, ${ }^{66}$ or that other Chinese entities had already acquired this know-how. ${ }^{67}$

National Supercomputing Centers. In 2015, BIS placed several of China's National Supercomputing Centers on the Entity List with presumptive denial of export licenses over national security concerns. These concerns arose from the development of the world's most powerful supercomputer, Sunway Taihulight, using Intel Xeon CPUs. ${ }^{68}$ But this export ban backfired. Without access to Intel's Xeon CPUs, these firms used domestically designed Sunway SW26010 chips instead, and from 2016 to 2018 Taihulight was the world's most powerful supercomputer anyway. ${ }^{69}$

\section{Military End-Use and End-User Controls}

The United States applies strict export controls for Chinese military end-uses and end-users beyond those imposed by the Commerce Control List on all Chinese entities. Although such controls have long existed, BIS expanded them in 2020. ${ }^{70}$ Today, an export to any Chinese end-user is controlled if it is for the use (i.e., operation, installation, maintenance, repair, overhaul, or refurbishment), development, or production of a military item; or if the export supports or contributes to those functions. Exports are further controlled for Chinese military end-users, which include armed forces, police, intelligence services, and "any person or entity whose actions or functions are intended to support 'military end uses.'" The latter policy is meant to address China's "military-civil fusion" initiatives. ${ }^{71}$

Military end-user and end-user controls apply only to the export of certain items listed on the Commerce Control List not otherwise controlled when exported to China; the new rules expand these items to cover a wide swath of semiconductor technologies, including various logic chips (including CPUs, FPGAs, and AI ASICs, but probably not GPUs) meeting performance thresholds, memory chips meeting storage thresholds, a wider variety of SME than those listed in Table 1, and other semiconductor technologies. ${ }^{72}$

Additionally, license applications for any of the controlled exports are subject to a presumption of denial. ${ }^{73}$ These requirements impose new controls on SME purchased by private Chinese chipmakers selling chips to the Chinese military. For example, in September 2020, the U.S. government notified U.S. SME firms that exports to China's leading chipmaker, Semiconductor 
Manufacturing International Corporation (SMIC), require an export license, because it sells chips to the military. ${ }^{74}$

\section{Validated End-User List}

VEUs are entities who have gone through a certification process and are allowed to receive certain U.S. exports under a general authorization, rather than under multiple individual export licenses. ${ }^{75}$ Except for Boeing and General Electric, all other firms on the VEU List are semiconductor firms. These firms include Chinese affiliates of the U.S. semiconductor firms AMD, Intel, Applied Materials, and Lam Research, as well as the South Korean semiconductor firms Samsung and SK Hynix. The rest are Chinese semiconductor firms, including one SME-maker, AMEC, and two Chinese chipmakers, Huahong Grace and CSMC. SMIC obtained VEU status in 2007, but in 2016, the United States removed SMIC from its VEU list at SMIC's request. $^{76}$ The United States requires VEUs to follow certain rules to maintain their status. In 2016 , SMIC likely either began collaborating with the Chinese government, or planned to, in a way that would violate its VEU status and therefore requested removal. 


\section{Semiconductor Exports and Export Licensing}

Despite export controls covering many critical semiconductor technologies, the United States continues to increase semiconductor technology exports to China, either because it does not export control these items or because it often grants export licenses. Although U.S. trade has remained stable as a whole in recent years, exports of semiconductors and SME have increased. This trend is driven by a decline in the scope of controlled semiconductor technologies and because of permissive export licensing policies.

Meanwhile, exports of materials used in semiconductor fabrication have decreased.

Total U.S. exports to China remained stable through 2018, with a dropoff in 2019 in the midst of U.S.-China trade tensions (Figure 1). The vast majority of exports are not impacted by export control laws. In 2019 , over 98 percent of all U.S. exports to China were not controlled. These numbers do not include license denials and exports forgone due to expected license denials or regulatory burdens of the export license application process. 
Figure 1: Total U.S. exports to China

Not controlled

Controlled (license exception)

Controlled (license approved)

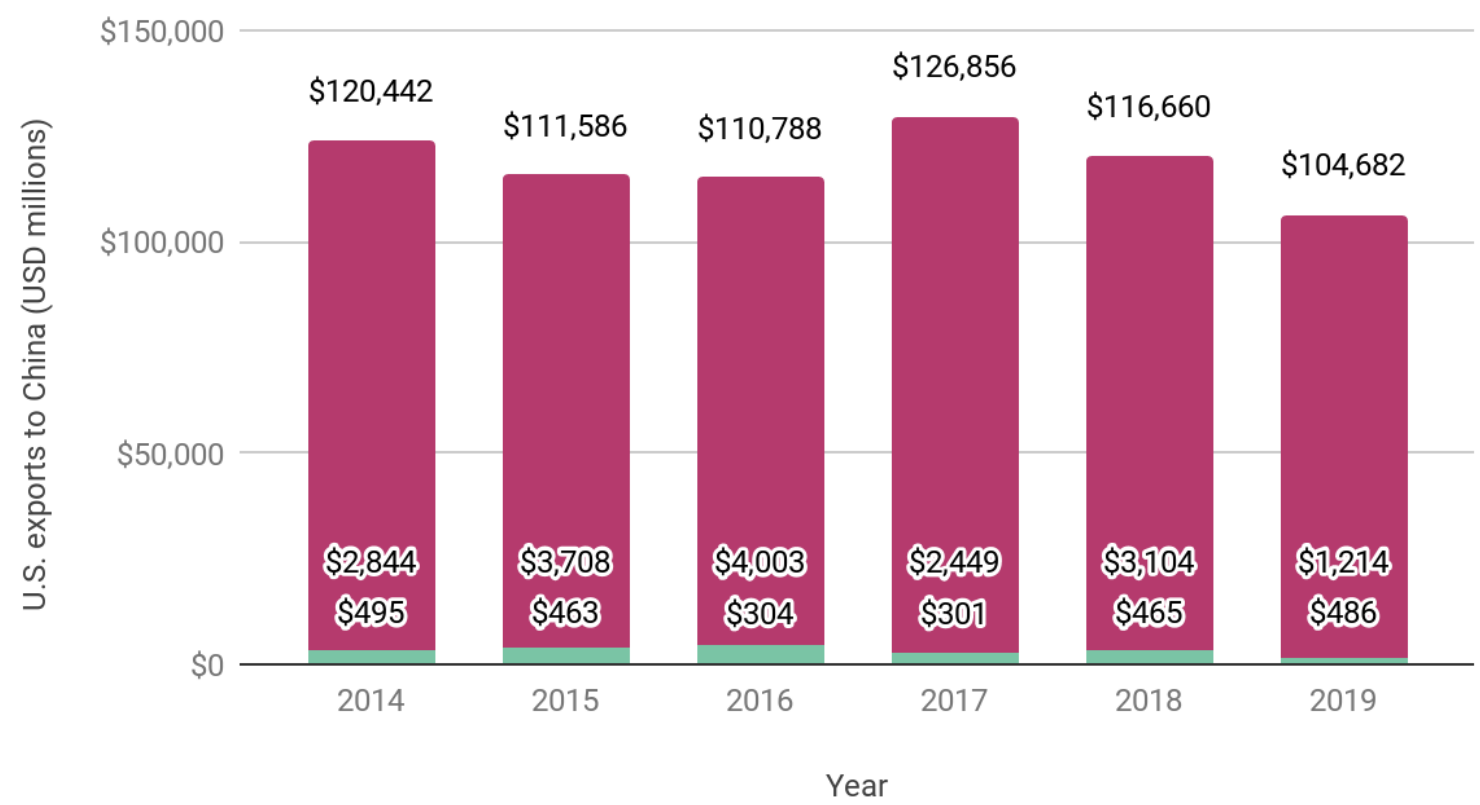

Note: Dollar values are nominal (not inflation-adjusted).

Sources: Bureau of Industry and Security, Asia Analysis, 2014-2019 China reports, https://www.bis.doc.gov/index.php/statistical-reports/country-analysis/asia.

By comparison, semiconductor exports to China have risen rapidly (Figures 2 through 4). Although exports of materials declined, exports of semiconductors and SME increased rapidly. One possible explanation is that Chinese firms were stockpiling chips and SME in preparation for possible future U.S. export bans. ${ }^{77}$ Another is that China was rapidly expanding its technological base. For example, the Chinese government is subsidizing SME purchases in excess of fab capacity, suggesting a goal to rapidly expand capacity. ${ }^{78}$ To an increasing degree, these exports include refurbished SME. ${ }^{79}$ Decreasing coverage of export controls may have played a role, including removal of certain SME from the Commerce Control List in 2016, as well as loosened controls on military-grade semiconductor technologies in $2014 .{ }^{80}$

Unfortunately, export data are lacking for other semiconductor sectors. Exports of IP-such as U.S. chip designs outsourced for fabrication at foreign fabs-are not counted in U.S. trade statistics. ${ }^{81}$ EDA software is also difficult to capture, especially if delivered as cloud services. 
Figure 2: U.S. semiconductor exports to China

Optoelectronics, sensors, and discretes

Chips

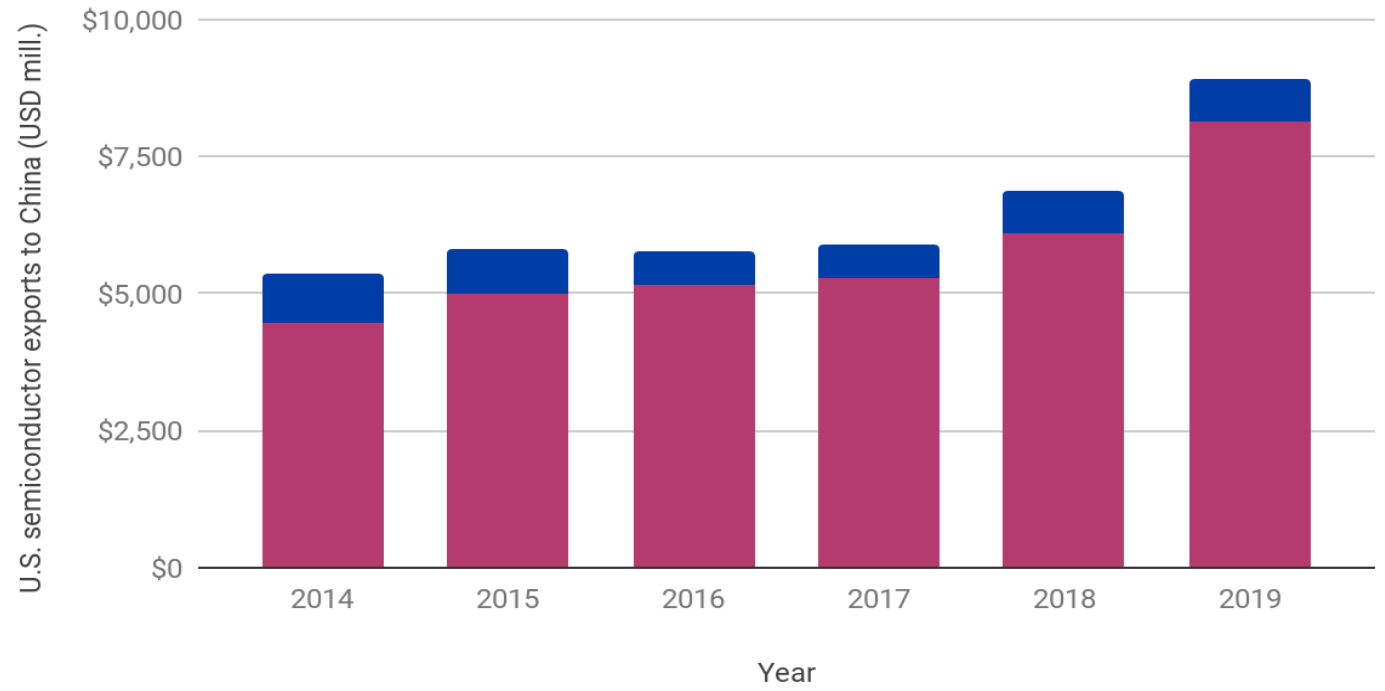

Note: Dollar values are nominal (not inflation-adjusted).

Source: U.S. Census export data, https://dataweb.usitc.gov/. ${ }^{82}$

Figure 3: U.S. SME exports to China

Assembly, testing, and packaging equipment $\square$ Fab equipment $\$ 5,000$

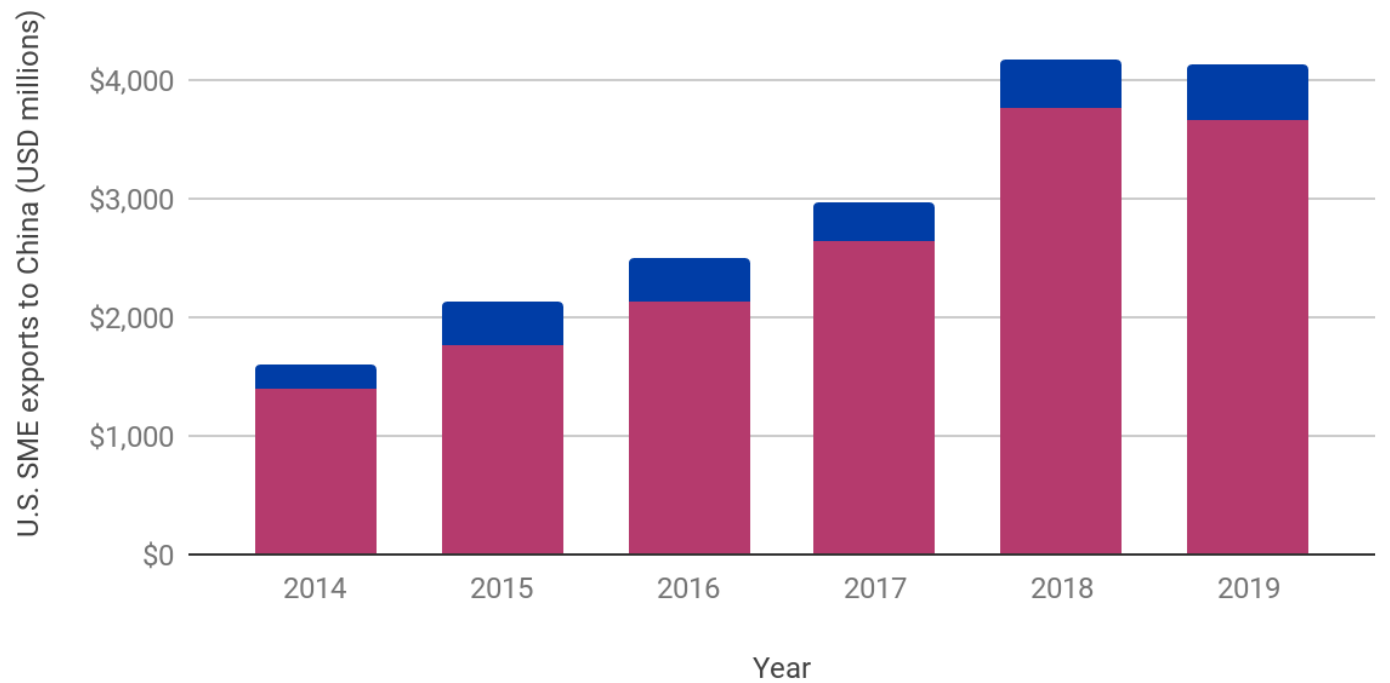

Note: Dollar values are nominal (not inflation-adjusted).

Source: U.S. Census export data, https://dataweb.usitc.gov/. ${ }^{83}$ 
Figure 4: U.S. materials exports to China

Wafers

Wafer material (highly pure silicon)

Wafer material (gallium arsenide, germanium, and silicon carbide)

Photographic plates (includes photomasks)

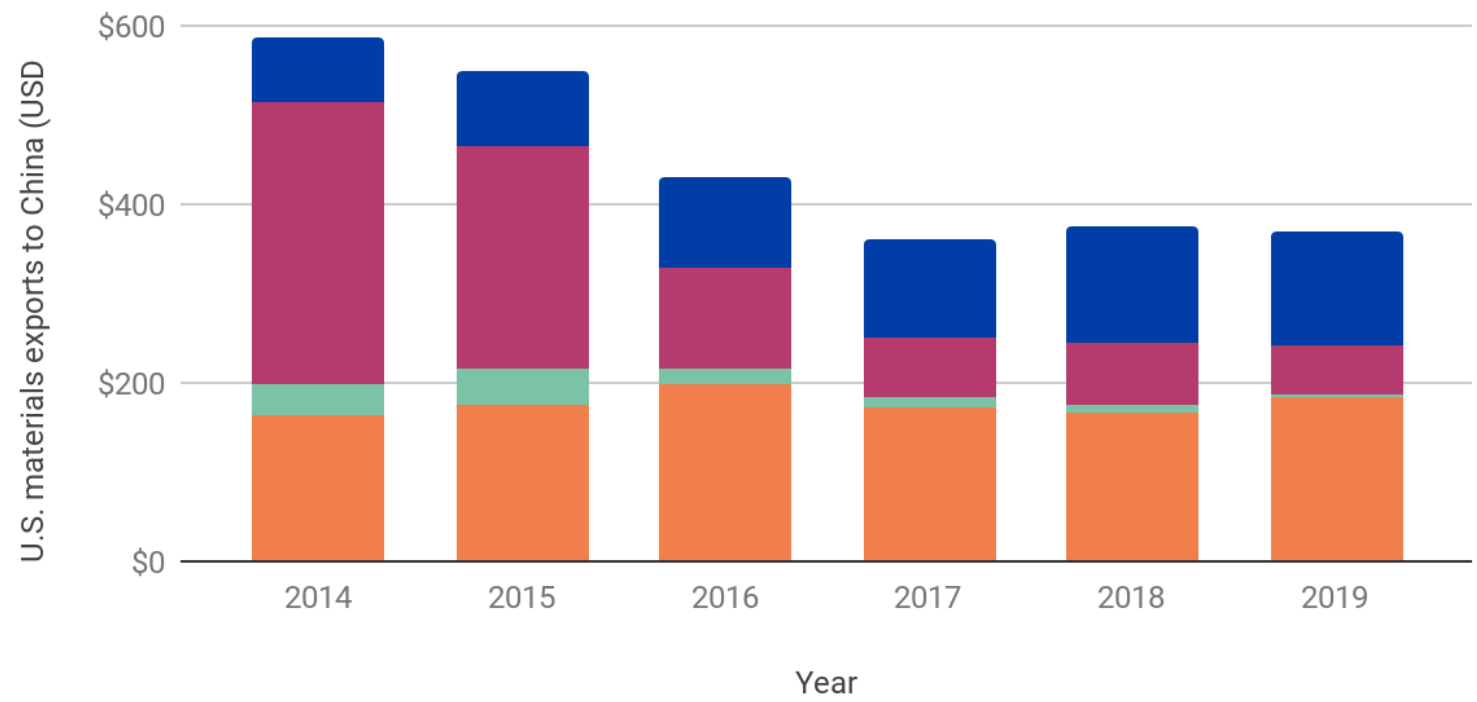

Note: Dollar values are nominal (not inflation-adjusted).

Source: U.S. Census export data, https://dataweb.usitc.gov/ ${ }^{84}$

The Bureau of Industry and Security publishes license application outcomes for Chinese exports, re-exports, and deemed exports (Figures 5 and 6). Export and re-export license applications were approved, denied, and returned without action (RWA) at stable rates between 2014 and 2019, except for an uptick in denials in 2019. ${ }^{85}$ During this period, export and reexport license approvals took about three weeks on average for all countries, and four to five weeks on average for China between 2014 and 2018 and nearly seven weeks in 2019. ${ }^{86}$ By comparison, in 2018, deemed export applications for Chinese nationals declined precipitously and RWA decisions increased, with a partial recovery in 2019 . (Recall, a U.S. employer must apply for a deemed export license for a foreign national who lacks a U.S. green card or U.S. citizenship and who would access controlled technical data or source code in the United States during their employment.) Deemed export applications for nationals of other countries did not experience the same decline. As a result, Chinese nationals comprised only 35 percent of approvals in 2018 , compared to 60 percent in the previous five years. By 2019 , approvals sometimes took six to eight months. ${ }^{87}$ 
Figure 5: U.S. license applications for exports and re-exports to China

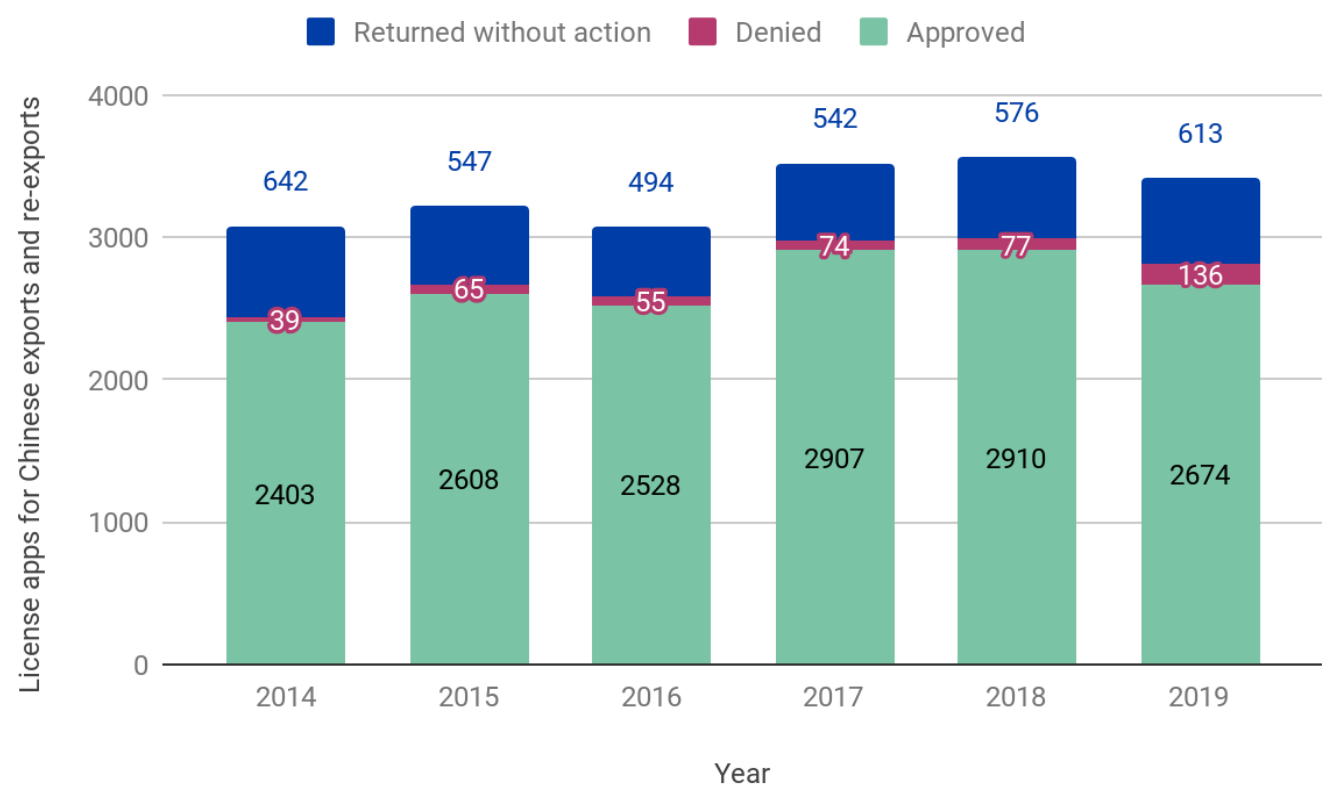

Source: Bureau of Industry and Security, Asia Analysis, 2014-2019 China reports, https://www.bis.doc.gov/index.php/statistical-reports/country-analysis/asia.

Figure 6: U.S. deemed export license applications for Chinese nationals

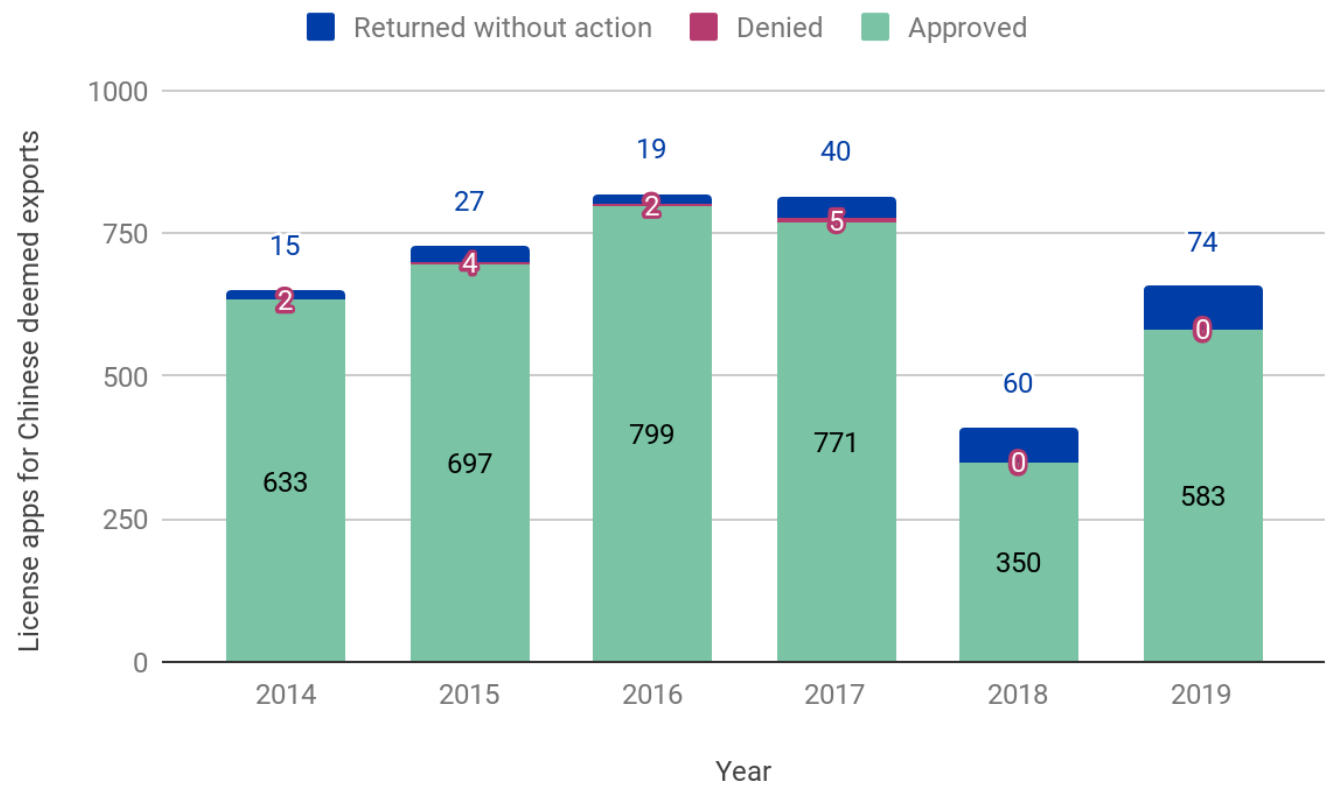

Source: Bureau of Industry and Security, Asia Analysis, 2014-2019 China reports, https://www.bis.doc.gov/index.php/statistical-reports/country-analysis/asia. 
In response to a Freedom of Information Act request, BIS disclosed more detailed export licensing data by technology categorization and destination country between 2010 and 2018 (Figures 7 and 8). This data aggregates export, re-export, and deemed export licenses applications. The results paint a similar picture for the semiconductor industry, with the majority of the 2018 decline in semiconductor license applications for China associated with semiconductor technical data (category $3 \mathrm{E}$ in figures 7 and 8 ), which include deemed export applications. ${ }^{88}$ The upper bound for Chinese-national highskill technical semiconductor and related industry workers currently working in the United States is approximately 6,000. Deemed export licensing delays have reportedly disrupted hundreds of jobs at U.S. semiconductor firms, including Intel, Qualcomm, and GlobalFoundries. ${ }^{89}$

Figure 7: Approved U.S. semiconductor license applications for Chinese exports, reexports, and deemed exports

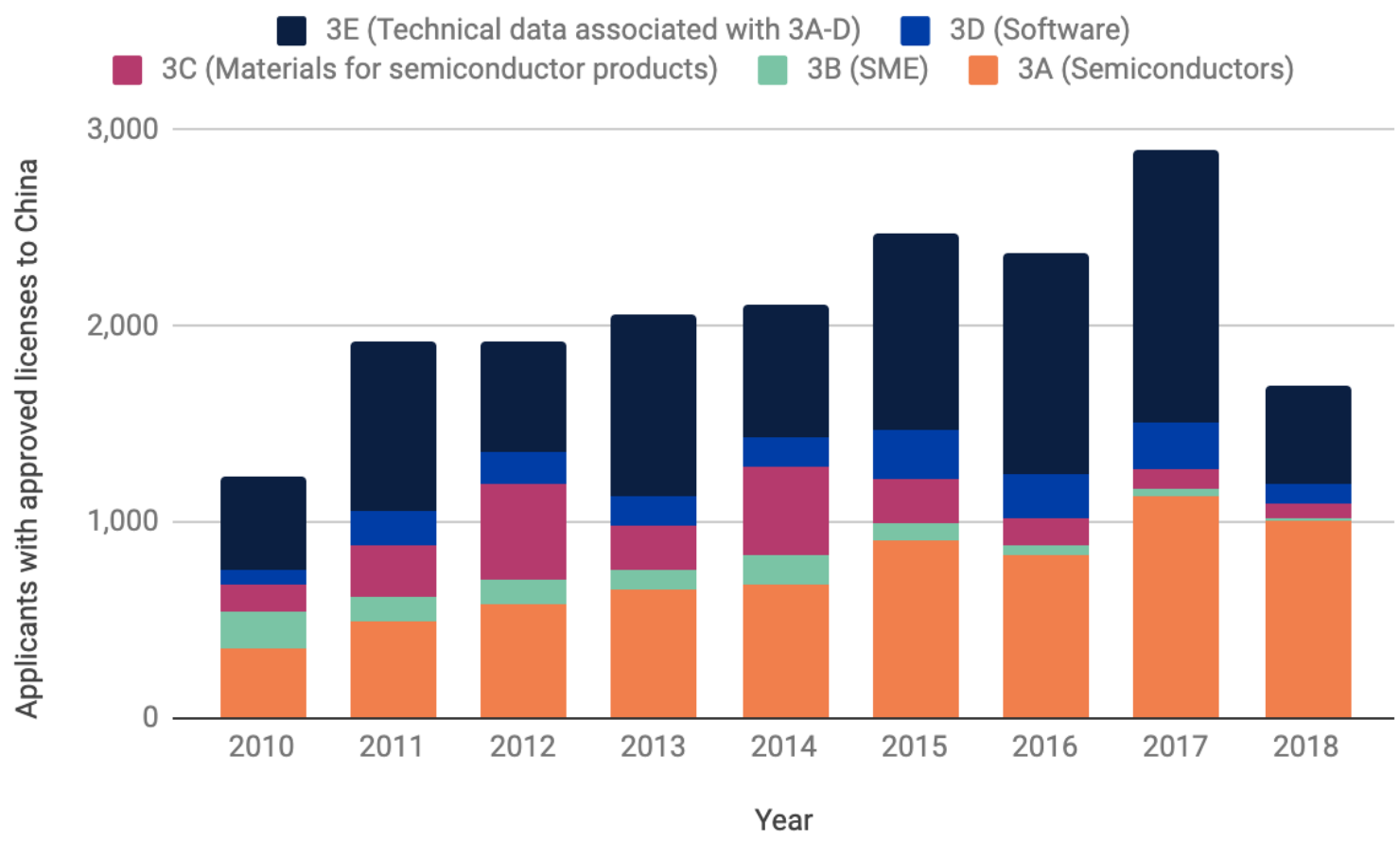

Source: Bureau of Industry and Security, export licensing statistics acquired using FOIA request and published by The Information, hitps://www.theinformation.com/tech-exports. ${ }^{90}$ 
Figure 8: Denied U.S. semiconductor license applications for Chinese exports, re-exports, and deemed exports

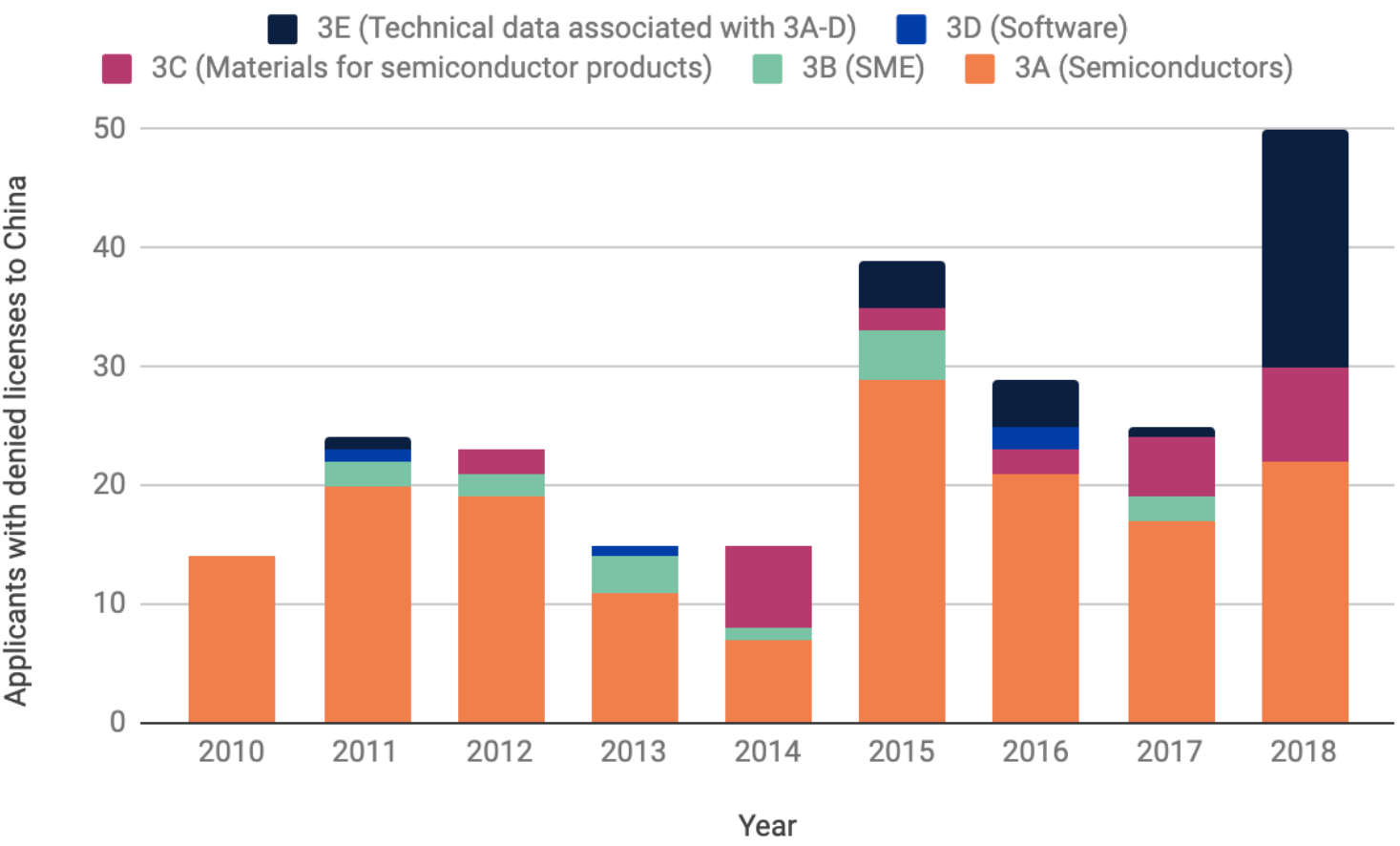

Source: Bureau of Industry and Security, export licensing statistics acquired using FOIA request and published by The Information, hitps://www.theinformation.com/tech-exports.

SME export licensing policy became more permissive until 2018. Historically, the U.S. government has often granted export licenses. A 2002 U.S.

Government Accountability Office report found that U.S. export-licensing policy for SME had been "unclear and inconsistent"; the United States approved most SME licenses, but "aimed at keeping China at least two generations (about 3 to 4 years) behind global state-of-the-art semiconductor manufacturing capabilities." ${ }^{91}$ By 2018, SME license applications notably dropped, suggesting export controls covered almost no SME exports. In 2018, only seven SME license applications were filed and all were approved (Figure 9). ${ }^{92}$ The most expensive SME, photolithography equipment, remains on the Commerce Control List, but U.S. firms sell little of it. Anisotropic dry etching equipment, which U.S. firms do sell, was removed from the Commerce Control List in 2016,93 coinciding with the drop in SME license applications. This explanation is consistent with the data in Figure 3 showing rapidly increasing SME exports to China since 2016. 
Figure 9: U.S. semiconductor license applications for SME exports to China

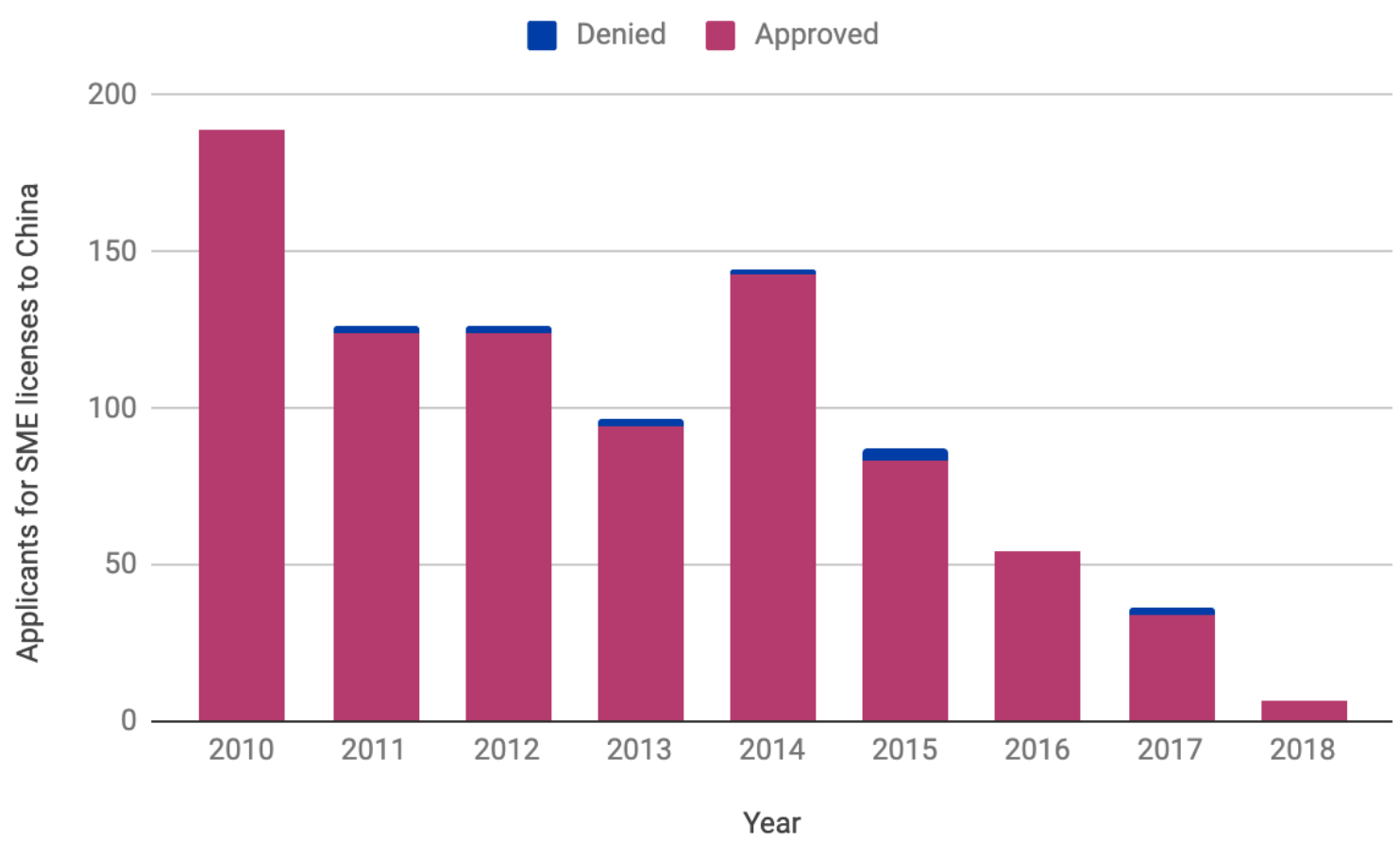

Source: Bureau of Industry and Security, export licensing statistics acquired using FOIA request and published by The Information, https://www.theinformation.com/tech-exports.

Recently, export controls and export licensing policy for SME exports have become more strict. First, in 2018, Chinese fab SMIC purchased ASML's EUV photolithography equipment, which is used to fabricate chips at the leading $7 \mathrm{~nm}$ and $5 \mathrm{~nm}$ nodes. ${ }^{94}$ ASML claimed it obtained the necessary export licenses, yet given backlogs, the equipment did not ship and the export license expired. ${ }^{95}$ ASML's equipment incorporates U.S.-origin components and intellectual property. Under pressure from the United States, the Dutch government did not renew the export license. ${ }^{96}$ Second, in 2020, BIS introduced stricter military end-use and end-user export controls and repealed civilian use exceptions for China. These rules require licenses for SME exports to Chinese chipmakers serving the military-such as SMIC-or for SME previously subject to a civilian use license exemption. License applications required by these rules are subject to a presumption of denial. ${ }^{97}$ Third, BIS is considering new export controls on SME. ${ }^{88}$ Fourth, in September 2020, Congress introduced a bill to tighten multilateral export controls on SME. ${ }^{99}$ 


\section{Conclusion}

The United States has historically controlled many exports of semiconductor technologies to China, given their strategic importance. China's rise and efforts to build up domestic semiconductor production have prompted the United States to further tighten these export controls.

Today, the United States controls exports of specific semiconductor technologies-including certain semiconductor manufacturing equipment, high-end chips, materials, software, and related technical data-to all Chinese entities. It also controls the acquisition of technical data or source code by Chinese nationals on U.S. soil. For these controls, the United States historically approved most export licenses.

On top of these controls, the United States restricts exports of a wider set of technologies to certain end-users and for certain end-uses in Chinaincluding many U.S. semiconductor technology consumers such as Huawei, China's supercomputing centers, certain Chinese chipmakers, and military end-uses and end-users. For these controls, the United States typically denies export licenses.

On balance, through 2018, export controls on semiconductor technology had relaxed, resulting in an expansion of exports to China, particularly of SME and chips. However, the United States has recently tightened export licensing policies and applied stricter controls on military end-uses and endusers, as well as on other major Chinese entities.

Going forward, the vital importance of semiconductors in national and international security will continue to place them at the center of the U.S. export control system. 


\section{Acknowledgments}

For helpful discussions, comments, and input, great thanks go to Carrick Flynn, Alex Friedland, Patrick Maloney, Alexander Mann, Igor MikolicTorreira, Dewey Murdick, Alexandra Vreeman, and Lynne Weil. The author is solely responsible for all mistakes.

\section{(c) $\underset{\mathrm{BY}}{\mathrm{BY}} \mathrm{NC}$}

(C) 2020 by the Center for Security and Emerging Technology. This work is licensed under a Creative Commons Attribution-Non Commercial 4.0 International License.

To view a copy of this license, visit https://creativecommons.org/licenses/by-nc/4.0/.

Document Identifier: doi: $10.51593 / 20200039$ 


\section{Endnotes}

' Semiconductors include several categories. The most important category is computer chips, which include logic chips (42 percent of sales in 2019, counting microprocessors, microcontrollers, and other logic chips), memory chips (26 percent), and analog chips (13 percent). Others include optoelectronics ( 10 percent), sensors (three percent), and discretes (six percent). "WSTS Semiconductor Market Forecast Spring 2020," World Semiconductor Trade Statistics, June 9, 2020, https://www.wsts.org/esraCMS/extension/media/f/WST/4622/WSTS_nr2020_05.pdf.

${ }^{2}$ These inputs include electronic design automation software and intellectual property used to design semiconductors; materials that become semiconductors; and the semiconductor manufacturing equipment used to manufacture, assemble, test, and package semiconductors. 3 "Measuring distortions in international markets: The semiconductor value chain" (Paris: Organisation for Economic Cooperation and Development, December 12, 2019), 39, https://doi.org/10.1787/8fe4491d-en.

${ }^{4}$ The Netherland's revenue service Belastingdienst implements these export controls. "Netherlands Export Control Information," Bureau of Industry and Security, accessed July 13, 2020. https://www.bis.doc.gov/index.php/all-articles/220-eco-countrypages/1048-netherlands-export-control-information.

${ }^{5}$ Japan's Ministry of Economy, Trade and Industry implements these export controls. "Japan Export Control Information," Bureau of Industry and Security, accessed July 13, 2020, https://www.bis.doc.gov/index.php/enforcement/oea?id=1 156.

${ }^{6}$ Germany's Federal Office of Economics and Export Control implements these export controls. "Germany Export Control Information," Bureau of Industry and Security, accessed July 13, 2020, https://www.bis.doc.gov/index.php/all-articles/220-eco-countrypages/1041-germany-export-control-information.

7 "Taiwan Export Control Information," Bureau of Industry and Security, accessed July 13, 2020, https://www.bis.doc.gov/index.php/all-articles/220-eco-country-pages/1155taiwan-export-control-information.

8 "Commerce Control List (CCL)," Bureau of Industry and Security, accessed July 13, 2020, https://www.bis.doc.gov/index.php/regulations/commerce-control-list-ccl

${ }^{9} 22$ C.F.R. \& 121.1 Category XI (2019).

${ }^{10}$ Table 1 focuses on items in Category 3 of the Commerce Control List, which covers electronics design, development, and production, but also includes some items from Category 1 (Materials, Chemicals, Microorganisms and Toxins), 2 (Materials Processing), and 4 (Computers).

"Depending on the type of technology, authority over the licensing decision is assigned to BIS, the Department of Defense's Defense Technology Security Administration (DTSA), or the Department of State. DTSA is typically more likely to deny licenses than BIS and State.

1283 Fed. Reg. 58,201 (Nov. 19, 2018) (revising 15 C.F.R. § 744), https://www.federalregister.gov/documents/2018/11/19/2018-25221/review-of- 
controls-for-certain-emerging-technologies; 85 Fed. Reg. 52,934 (Aug. 27, 2020) (revising 15 C.F.R. § 742, 774),

https://www.federalregister.gov/documents/2020/08/27/2020-18910/identificationand-review-of-controls-for-certain-foundational-technologies. For examples of potential restrictions, see Alexandra Alper, "U.S. finalizing rules to limit sensitive tech exports to China, others," Reuters, December 17, 2019, https://www.reuters.com/article/us-usa-tech-chinaexclusive/exclusive-us-finalizing-rules-to-limit-sensitive-tech-exports-to-china-othersidUSKBNIYL1B8.

${ }^{13}$ Many of the export controls in the Commerce Control List are applied to countries with a "national security" designation. There are two "national security" country lists-NS-1 and NS-2-and China is included in both. A wider array of technologies is controlled for a small number of countries that have an "anti-terrorism" designation (which does not include China). ECCNs 3A991-999, 3B991-992, 3C992, 3D991, and 3E991. For the country lists, see 15 C.F.R. Supplement No. 1 to $\S 738$, https://www.bis.doc.gov/index.php/documents/regulations-docs/federal-registernotices/federal-register-2014/1033-738-supp-1/file.

${ }^{14}$ For more information on the role of different types of SME, see John VerWey, The Health and Competitiveness of the U.S. Semiconductor Manufacturing Equipment Industry

(Washington, DC: U.S. International Trade Commission, July 2019), 3, https://www.usitc.gov/publications/332/working_papers/id_058_the_health_and_com petitiveness of the sme industry final 070219 checked.pdf. SME specially designed for making ASICs designed for military items and FPGAs programmed for military items are more broadly controlled. ECCN 3B611 (NS-1 countries).

${ }^{15} \mathrm{ECCN} 3 \mathrm{~B} 001$ 1.e (NS-2 countries); ECCN 3E001 (NS- 1 countries).

${ }^{16} \mathrm{ECCN} 3 \mathrm{BO0} 1 . \mathrm{b}, 3 \mathrm{~B} 001$.e, and 2B005.b, (NS-2 countries); ECCN 3E001, 2E001, and 2E002 (NS- 1 countries).

${ }^{17} \mathrm{ECCN} 3 \mathrm{~B} 001$.a, 3B00 1.e, 2B005.a, and 2B005.c-f (NS-2 countries); ECCN 3E001, 2E001, 2E002, and 2E003.f (NS-1 countries).

${ }^{18}$ ECCN 3B00 1.f. 1 (NS-2 countries); ECCN 3E00 I (NS-1 countries). EUV scanners are the most advanced photolithography tools, necessary for fabricating chips at the $5 \mathrm{~nm}$ node. Argon fluoride (ArF) immersion scanners are the next most advanced. EUV or ArF immersion scanners are necessary for fabricating chips between the $45 \mathrm{~nm}$ and $7 \mathrm{~nm}$ nodes. Robert Castellano, "Canon's Nanoimprint Lithography: A Chink In ASML Holding's Armor," Seeking Alpha, March 19, 2019, hitps://seekingalpha.com/article/4249762-canonsnanoimprint-lithography-chink-asml-holdings-armor. ECCN 3B00 1.f. 1.b controls photolithography tools "[c]apable of producing a pattern with a 'Minimum Resolvable Feature size' (MRF) of $45 \mathrm{~nm}$ or less." At first glance, this clause appears to cover ArF immersion scanners. However, a technical note defines MRF as (an exposure light source wavelength in $\mathrm{nm}) \times(\mathrm{K}$ factor $=0.35) /$ numerical aperture. All ArF immersion scanners have a $193 \mathrm{~nm}$ light source and the most advanced ArF immersion scanners reach a numerical aperture of 1.35. ASML, "TWINSCAN NXT:2000i," accessed September 3, 2020, https://www.asml.com/en/products/duv-lithography-systems/twinscan-nx+2000i. These values result in an MRF of $50 \mathrm{~nm}$, avoiding controls.

${ }^{19}$ ECCN 3B00 1.f.2 (NS-2 countries); ECCN 3E00 1 (NS-1 countries). 
${ }^{20}$ ECCN 3B00 1.f.3 (NS-2 countries); ECCN 3E00 1 (NS-1 countries).

${ }^{21} \mathrm{ECCN} 3 \mathrm{BO0} 2$ (NS-2 countries); ECCN 3E001 (NS- 1 countries).

${ }^{22} \mathrm{ECCN} 3 \mathrm{D} 001-005$ (NS-1 countries). Military-use software is more broadly controlled. ECCN 3D6 11 (NS- 1 countries).

${ }^{23} \mathrm{ECCN} 3 \mathrm{D003}$ (NS-1 countries) is not interpreted as covering EDA software. See also "EDAC urges U.S. to ease export rules," EETimes, July 19, 2004, https://www.eetimes.com/document.asp? doc id =1217839 (discussing past arguments on the applicability of ECCN 3D003 to EDA software). See also ECCN 3E002 (NS-1 countries).

${ }^{24}$ ASICs designed for military items and FPGAs programmed for military items are more broadly controlled. ASICs designed for less-sensitive military items are controlled under ECCN 3A6 11 .f and 3A6 1 1.y. 14 (NS-1 countries) while ASICs and FPGAs designed for more-sensitive military items are controlled by the U.S. International Traffic in Arms Regulation (ITAR) export control regime under the U.S. Munitions List. 22 C.F.R. § 121.1 Category $\mathrm{XI}(\mathrm{c})$ (1) (2019). Additionally, ECCN 3A001.a.3 covers (though not for civilian uses) microprocessors using compound semiconductors like gallium arsenide rather than elemental semiconductors like silicon. Therefore, Table 1 only reflects export control coverage for chips with elemental semiconductors like silicon, which is used in Al-relevant chips. Finally, the Commerce Control List also lists a large number of semiconductors in addition to the key items listed in Table 1.

${ }^{25}$ ECCN 3A991.a (AT countries) does not include China; ECCN 3E002 (NS-1 countries); "AMD Regulatory Trade Compliance," AMD, Accessed July 13, 2020, https://www.amd.com/en/corporate-responsibility/trade-compliance.

${ }^{26}$ ECCN 3A991.a (AT countries) does not include China.

${ }^{27}$ ECCN 3A00 1.a.7 (NS-2 countries); ECCN 3E00 1 (NS-1 countries). A broader range of FPGAs are controlled for countries, not including China, with an "anti-terrorism" designation. ECCN 3A991.d (AT countries).

${ }^{28} \mathrm{ECCN} 3 \mathrm{A00} 1$.a. 9 (NS-2 countries) lists "neural network integrated circuits," which the U.S. Commerce Control List has listed at least as far back as 2003. Revision of Export Controls for General Purpose Microprocessors, 68 Fed. Reg. 1796 (Jan. 14, 2003) (revising 15 C.F.R. § 744), https://www.federalregister.gov/documents/2003/01/14/03-714/revision-of-exportcontrols-for-general-purpose-microprocessor. See ECCN 3E00 1 (NS- 1 countries) for related technical data controls. However, neural network integrated circuits are likely not interpreted as covering AI ASICs. ECCN 4A004.b (NS-2 countries) lists "neural computers" which are defined as "computational devices designed or modified to mimic the behaviour of a neuron or a collection of neurons, i.e., computational devices which are distinguished by their hardware capability to modulate the weights and numbers of the interconnections of a multiplicity of computational components based on previous data." It is unclear whether this category covers any AI ASICs. See ECCN 4EOO 1 (NS-1 countries) for related technical data controls. For more discussion, see Roszel C. Thomsen II, "Artificial Intelligence and Export Controls: Conceivable, But Counterproductive?," Journal of Internet Law 22, no. 5 (November 2018): 16, https://t-b.com/wp-content/uploads/2019/01/Al-and-ExportControls-Journal-of-Internet-Law-Article.pdf; Chris Timura, Sarah Banco, and Charlotte 
Bernard, "Practical Guidance On Managing New Foreign Investment Review Requirements and Export Controls on Emerging Technologies," Association of Corporate Counsel, July 10, 2019, 15, https://www.acc.com/sites/default/files/2019-07/7.10.19\%20Slides.pdf. ${ }^{29} \mathrm{ECCN} 3 \mathrm{CO} 1$ and $3 \mathrm{COO} 6$ (NS-2 countries); ECCN 3E00 1 (NS- 1 countries).

${ }^{30} \mathrm{ECCN} 3 \mathrm{CO0} 5$ (NS-2 countries); ECCN 3E00 1 (NS-1 countries).

${ }^{31}$ ECCN 3B00 1.g-i (NS-2 countries); ECCN 3EO0 1 (NS-1 countries). Throughout, the term "mask" is intended to include photomasks, reticles, and stamps. Photomasks and reticles are used in photolithography. A photomask's pattern has a 1:1 correspondence to a desired wafer pattern, while a reticle's pattern corresponds to only part of a desired wafer pattern. Therefore, the reticle must be moved relative to the wafer to transfer the reticle's pattern multiple times to create a repeating pattern on the wafer. A stamp is similar to a photomask, except it is used for imprint lithography rather than photolithography.

${ }^{32}$ ECCN 3 CO02 (NS-2 countries); ECCN 3E001 (NS-1 countries).

${ }^{33} \mathrm{ECCN} 1 \mathrm{C} 350$. d. 14 (CB-2 countries); ECCN $1 \mathrm{E} 350$ and $1 \mathrm{E} 351$ (CB-2 countries).

${ }^{34}$ ECCN 3C003-004 (NS-2 countries); ECCN 3E00 1 (NS- 1 countries). These materials include certain compounds having organic and inorganic materials, and hydrides of phosphorus, arsenic, or antimony.

${ }^{35}$ The U.S. origin content counts toward the threshold percentage if the item is a (1) non-U.S.made tangible item that "incorporates" the content, where that content is a controlled U.S.origin tangible item, (2) non-U.S.-made tangible item that is "bundled" with the content, where that content is controlled U.S.-origin software, (3) non-U.S.-made software that "incorporates" the content, where that content is controlled U.S.-origin software, or (4) nonU.S.-made technical data that is "commingled with or drawn from" the content, where that content is controlled U.S.-origin technical data. 15 C.F.R. § 734.4 (2019); 15 C.F.R. Supplement No. 2 to $\S 734$ (2019); Bureau of Industry and Security, "De minimis Rules and Guidelines," November 5, 2019,

https://www.bis.doc.gov/index.php/documents/pdfs/1382-de-minimis-guidance/file.

${ }^{36}$ These chips are listed under ECCN 3A00 1 (NS-2 countries) and 3A6 11 (NS-1 countries).

${ }^{37}$ Bureau of Industry and Security, "De minimis Rules."

${ }^{38}$ Because regulations do not define the term "direct product," it is difficult to make a definitive judgment as to whether the foreign-produced ruled direct produce applies in certain cases. 15 C.F.R. § 736.2(b)(3) (2019).

${ }^{39}$ Other designations could also capture China.

${ }^{40}$ The Wassenaar Arrangement does not include an entity list. However, many other Wassenaar Arrangement members maintain similar lists. Japan, "End User List," https://www.meti.go.jp/press/2017/05/20170524001/20170524001-1.pdf; Taiwan, "Strategic high-tech goods export entity management list" [我國戰略性高科技貨 品出口實體管理名單],

https://ekm 101.trade.gov.tw/ckfinder/connector? command=Proxy\&type=Files\&currentFol der $=\% 2$ F\&fileName $=1081125 \%$ E6 \%88\%91\%E5\%9C\%8B\%E6\%88\%B0\%E7\%95\%A5\%E6 \%80\%A7\%E9\%AB\%98\%E7\%A7\%91\%E6\%8A\%80\%E8\%B2\%A8\%E5\%93\%81\%E5\%87\%B A\%E5\%8F\%A3\%E5\%AF\%A6\%E9\%AB\%94\%E7\%AE\%A1\%E7\%90\%86\%E5\%90\%8D\%E5\% 
96\%AE.pdf\&cache=31536000; South Korea, "Denial List,"

https://www.yestrade.go.kr/common/common.do?jPath=/ia/iaEa081C\#.

41 "Denied Persons List," U.S. Department of Commerce Bureau of Industry and Security, accessed July 13, 2020, https://www.bis.doc.gov/index.php/policy-guidance/lists-ofparties-of-concern/denied-persons-list.

${ }^{42}$ Expansion of Export, Reexport, and Transfer (in-Country) Controls for Military End Use or Military End Users in the People's Republic of China, Russia, or Venezuela, 85 Fed. Reg. 23,459 (April 28, 2020) (revising 15 C.F.R. § 732, 734, 738, 742, 744, 758, and 774), https://www.federalregister.gov/documents/2020/04/28/2020-07241/expansion-ofexport-reexport-and-transfer-in-country-controls-for-military-end-use-or-military-end; Expansion of Export, Reexport, and Transfer (In-Country) Controls for Military End Use or Military End Users in the People's Republic of China, Russia, or Venezuela; Correction, 85 Fed. Reg. 34,306 (June 3, 2020) (revising 15 C.F.R. § 774), https://www.federalregister.gov/documents/2020/06/03/2020-09717/expansion-ofexport-reexport-and-transfer-in-country-controls-for-military-end-use-or-military-end. 43 "Debarred Parties," U.S. Department of State Directorate of Defense Trade Controls, accessed July 13, 2020,

https://www.pmddtc.state.gov/ddtc_public?id=ddtc_kb_article_page\&sys_id=c22d1833d bb8d300d0a370131f9619f0.

44 "Specially Designated Nationals And Blocked Persons List (SDN) Human Readable Lists," U.S. Department of the Treasury, July 10, 2020, https://www.treasury.gov/resourcecenter/sanctions/sdn-list/pages/default.aspx.

${ }^{45} 15$ C.F.R. Supplement No. 4 to $\S 744$, https://www.bis.doc.gov/index.php/documents/regulations-docs/2326-supplement-no4-to-part-744-entity-list-4/file.

${ }^{46}$ These technologies include items on the Commerce Control List plus items not on the list. The latter are called "EAR99" items.

${ }^{47}$ Exceptions include "[g]eneral scientific, mathematical, or engineering principles commonly taught in schools, colleges, and universities," "basic marketing information on function or purpose or general system descriptions of controlled items," or "[p]ublic domain information which is published and is accessible or available to the public, unrestricted: publications \& conferences, patents, fundamental research." 22 CFR § 120.10.

${ }^{48}$ Addition of Certain Entities; and Modification of Entry on the Entity List, 83 Fed. Reg. 37,423 (August 1, 2018) (revising 15 C.F.R. § 744), https://www.federalregister.gov/documents/2018/08/01/2018-16474/addition-ofcertain-entities-and-modification-of-entry-on-the-entity-list.

${ }^{49}$ Addition of Certain Entities to the Entity List, 84 Fed. Reg. 54,002 (October 9, 2019) (revising 15 C.F.R. § 744), https://www.federalregister.gov/documents/2019/10/09/2019-22210/addition-ofcertain-entities-to-the-entity-list.

${ }^{50}$ Addition of an Entity to the Entity List, 83 Fed. Reg. 54,519 (October 30, 2018) (revising 15 C.F.R. § 744), https://www.federalregister.gov/documents/2018/10/30/201823693/addition-of-an-entity-to-the-entity-list. China's president Xi Jinping had designated Chinese memory chip makers Fujian Jinhua, Hefei Changxin, and Tsinghua Unigroup's 
Yangtze River Memory as China's three future champions of memory chipmaking. David McLaughlin and Chris Strohm, "China State-Owned Company Charged With Micron Secrets Theft," Bloomberg, November 1, 2018, https://www.bloomberg.com/news/articles/2018-11-01/u-s-says-china-state-ownedco-stole-micron-trade-secrets.

51 "The Chipmaker Caught in U.S. Assault on China's Tech Ambitions," Bloomberg, November 28, 2018, https://www.bloomberg.com/news/articles/2018-11-25/thechipmaker-caught-in-u-s-assault-on-china-s-tech-ambitions.

${ }^{52}$ Japan's export control agency, the Ministry of Economy, Trade and Industry, gave no instructions to Japanese SME firms. Additionally, these firms suggested that the de minimis rule would not apply Japanese SME exports to China, as such exports do not include sufficient U.S.-origin content. Makiko Yamazaki. "Exclusive: Top Japanese chip gear firm to honor U.S. blacklist of Chinese firms - executive," Reuters, June 11, 2019, https://www.reuters.com/article/us-usa-trade-china-semiconductors-exclus/exclusive-topjapanese-chip-gear-firm-to-honor-us-blacklist-of-chinese-firms-executive-idUSKCN I TCOH6. ${ }^{53}$ Kathrin Hille, "Trade war forces Chinese chipmaker Fujian Jinhua to halt output," Financial Times, January 28, 2019, https://www.ft.com/content/87b5580c-22bf-1 1e9-8ce65db4543da632.

${ }^{54}$ Bureau of Industry and Security, "Huawei Temporary General License Extension Frequently Asked Questions (FAQs)," May 18, 2020, https://www.bis.doc.gov/index.php/documents/pdfs/2446-huawei-entity-list-temporarygeneral-license-extension-faqs/file.

${ }^{55}$ U.S. Department of Commerce, "U.S. Department of Commerce Extends Huawei Temporary General License," November 18, 2019, https://www.commerce.gov/news/press-releases/2019/11/us-department-commerceextends-huawei-temporary-general-license.

${ }^{56}$ Addition of Huawei Non-U.S. Affiliates to the Entity List, the Removal of Temporary General License, and Amendments to General Prohibition Three (Foreign-Produced Direct Product Rule), 85 Fed. Reg. 51,596 (August 17, 2020) (revising 15 C.F.R. § 736, 744, and 762), hitps://www.federalregister.gov/documents/2020/08/20/2020-

18213 /addition-of-huawei-non-us-affiliates-to-the-entity-list-the-removal-of-temporarygeneral-license-and.

${ }^{57}$ Intel can use its foreign fabs in Ireland or Israel to supply Huawei. Cecilia Kang and Paul Mozur, "U.S. Tech Companies Sidestep a Trump Ban, to Keep Selling to Huawei," The New York Times, June 25, 2019, https://www.nytimes.com/2019/06/25/technology/huawei-trump-ban-technology.html; lan King and Jenny Leonard, "U.S. Companies Find Legal Ways Around Trump's Huawei Blacklist," Bloomberg, June 25, 2019, https://www.bloomberg.com/news/articles/201906-26/u-s-companies-are-finding-a-legal-way-around-huawei-blacklist. The U.K. firm Arm, which licenses IP cores for Huawei's chip designs, initially stopped working with Huawei based on its determination that its designs include "U.S.-origin technology" (likely meaning technical data). Dave Lee, "Huawei: ARM memo tells staff to stop working with China's tech giant," BBCNews, May 22, 2019. https://www.bbc.com/news/technology-48363772. Arm later resumed sales to Huawei and stated that its designs were U.K.-origin. "ARM and 
Qualcomm Will Continue to Supply Huawei Despite US Ban," Synced, September 26, 2019, https://syncedreview.com/2019/09/26/arm-and-qualcomm-will-continue-tosupply-huawei-despite-us-ban/.

${ }^{58}$ Yoko Kubota and Dan Strumpf, "American Threat to Huawei's Chip Maker Shows Chinese Tech Isn't Self-Sufficient," The Wall Street Journal, June 2, 2019,

https://www.wsi.com/articles/huaweis-main-chip-maker-faces-long-term-risks-from-u-sban-11559467846.

${ }^{59}$ Cheng Ting-Fang and Lauly Li, "Huawei loses access to vital chip design updates from Synopsys," Nikkei Asian Review, May 31, 2019,

https://asia.nikkei.com/Spotlight/Huawei-crackdown/Huawei-loses-access-to-vital-chipdesign-updates-from-Synopsys.

6085 Fed. Reg. 51,596. A previous, superceded version of expanded re-export rules prevented Huawei from obtaining chips manufactured by non-U.S. foundries using U.S. SME and based on Huawei's chip designs. U.S. Department of Commerce, "Commerce Addresses Huawei's Efforts to Undermine Entity List, Restricts Products Designed and Produced with U.S. Technologies," May 15, 2020, https://www.commerce.gov/news/pressreleases /2020/05/commerce-addresses-huaweis-effortsat TSMC-undermine-entity-listrestricts. These rules would not have prevented TSMC from shipping chips to Huawei that were not designed by Huawei, as TSMC claims its exports to Huawei do not fall under the original entity listing. "Taiwan's computing titans are caught up in the US-China tech war," Economist, June 8, 2019, https://www.economist.com/business/2019/06/06/taiwanscomputing-titans-are-caught-up-in-the-us-china-tech-war. TSMC argued that U.S.-origin IP and materials counts toward the de minimis rule for its chip production, but U.S.-origin SME does not. Kensaku lhara, Cheng Ting-Fang and Lauly Li, "TSMC says its chips for Huawei do not fall under US hammer," Nikkei Asian Review, May 23, 2019, https://asia.nikkei.com/Spotlight/Huawei-crackdown/TSMC-says-its-chips-for-Huaweido-not-fall-under-US-hammer. However, the de minimis rule states that U.S.-origin IP's contribution to foreign re-exports of commodities should not count toward the de minimis rule. ${ }^{61}$ Iris Deng, "Huawei will use its own phone chips amid report UK design firm ARM has cut business ties, says analyst," South China Morning Post, May 23, 2019, https://www.scmp.com/tech/big-tech/article/301 1437/huawei-will-use-its-own-phonechips-amid-report-uk-design-firm-arm.

${ }^{62}$ From 2018 to 2019, the percentage of Huawei phones with Qualcomm chips dropped from 24 percent to 8.6 percent, with MediaTek chips rising from 7.3 percent to 16.7 percent. Jusy Hong, "DIY chips: Samsung and Huawei increasingly turn to in-house application processors for their smartphone lines," Informa Tech, January 6, 2020, https://web.archive.org/web/20200417120324/https://technology.informa.com/620 106/diy-chips-samsung-and-huawei-increasingly-turn-to-in-house-application-processorsfor-their-smartphone-lines.

${ }^{63}$ Kate O'Keeffe and Brian Spegele, "How a Big U.S. Chip Maker Gave China the 'Keys to the Kingdom'," The Wall Street Journal, June 27, 2019, https://www.wsi.com/articles/u-stried-to-stop-china-acquiring-world-class-chips-china-got-them-anyway-11561646798.

${ }^{64}$ Kate O'Keeffe and Asa Fitch, "U.S. Targets China's Supercomputing Push With New Export Restrictions," The Wall Street Journal, June 21, 2019, 
https://www.wsi.com/articles/u-s-targets-chinas-supercomputing-push-with-new-exportrestrictions-1 1561 129547; Addition of Entities to the Entity List and Revision of an Entry on the Entity List, 84 Fed. Reg. 29,371 (June 24, 2019) (revising 15 C.F.R. § 744), https://www.federalregister.gov/documents/2019/06/24/2019-13245/addition-ofentities-to-the-entity-list-and-revision-of-an-entry-on-the-entity-list.

${ }^{65} \mathrm{O}^{\prime}$ Keeffe, "Keys to the Kingdom."

${ }^{66}$ Stewart Randall, "Did AMD really give away 'keys to the kingdom'?," TechNode, July 10, 2019, https://technode.com/2019/07/10/did-amd-really-give-away-keys-to-thekingdom/.

${ }^{67}$ Chinese chip designer Zhaoxin has developed $\times 86$ CPUs in a joint venture with Taiwanese chip designer VIA Technologies, which has a minor foothold in the $\times 86$ market. Paul Alcorn, "Zhaoxin KaiXian $\times 86$ CPU Tested: The Rise of China's Chips," Tom's Hardware, April 10, 2020, https://www.tomshardware.com/features/zhaoxin-kx-u6780a-x86-cpu-tested. ${ }^{68}$ Addition of Certain Persons to the Entity List; and Removal of Person From the Entity List Based on a Removal Request, 80 Fed. Reg. 8524 (February 18, 2015) (revising 15 C.F.R. § 744), hitps://www.federalregister.gov/documents/2015/02/18/2015-

$03321 /$ addition-of-certain-persons-to-the-entity-list-and-removal-of-person-from-the-entitylist-based-on-a.

${ }^{69}$ Brian Barrett, "China's New Supercomputer Puts the US Even Further Behind." Wired, June 21, 2016, https://www.wired.com/2016/06/fastest-supercomputer-sunway-taihulight/. It is unclear whether the Sunway chips were fabricated at Taiwanese fab TSMC or at a local Chinese fab.

7085 Fed. Reg. 23,459.

${ }^{71}$ Judith Alison Lee, Chris Timura, R.L. Pratt, Samantha Sewall, Laura Cole and Josh Shuo Zhang, "U.S. Moves to Tighten Export Controls on China and other Jurisdictions with Policies of Civil-Military Fusion," Gibson Dunn, May 4, 2020, https://www.gibsondunn.com/usmoves-to-tighten-export-controls-on-china-and-other-jurisdictions-with-policies-of-civilmilitary-fusion/.

${ }^{72}$ For example, they cover all items listed under ECCNs 3A991, 3A992, 3A999, 3B991, 3B992, 3C992, and 3D991, among others. ECCN 3A991 covers CPUs and AI ASICs. The plain language of ECCN 3A991 arguably cover GPUs, but GPU-maker AMD classifies its GPUs as "EAR99," which applies to dual-use items not listed on the Commerce Control List. AMD, "AMD Regulatory Trade Compliance." FPGAs are controlled under 3A001.a.7. ${ }^{73}$ John P. Barker, Soo-Mi Rhee, Nicholas L. Townsend, Tom McSorley, Emma Dinan, Junghyun Baek, Trevor G. Schmitt, "The US Further Restricts Exports to China, Russia and Venezuela-Including Many Commercial Electronics Items and Software," Arnold and Porter, April 30, 2020, https://www.arnoldporter.com/en/perspectives/publications/2020/04/us-restrictsexports-to-china-russia-venezuela.

${ }^{74}$ Dan Strumpf, "U.S. Sets Export Controls on China's Top Chip Maker," The Wall Street Journal, September 28, 2020, https://www.wsi.com/articles/u-s-sets-export-controls-onchinas-top-chip-maker-11601118353. 
7515 C.F.R. Supplement 7 to $\S 748$.

https://www.bis.doc.gov/index.php/documents/validated-end-user/457-supplement-no7-to-part-748-veu-list/file.

${ }^{76}$ Amendment to the Export Administration Regulations: Removal of Semiconductor Manufacturing International Corporation From the List of Validated End-Users in the People's Republic of China, 81 Fed. Reg. 87,426 (December 5, 2015) (revising 15 C.F.R. § 748), https://www.bis.doc.gov/index.php/documents/regulations-docs/federal-registernotices/federal-register-2016/1611-81-fr-87426/file.

77 Data on China's imports from all countries tell a similar tale. While China's imports as a whole are declining, China's imports of chips and SME have been increasing. "China Stockpiles Foreign Tech as 'Silicon Curtain' Descends," Bloomberg, December 3, 2019, https://www.bloomberg.com/news/articles/2019-12-03/china-stockpiles-foreign-techas-silicon-curtain-descends.

78 "Economics and Trade Bulletin," (Washington, DC: U.S.-China Economic and Security Review Commission, January 1 1, 2019), 9,

https://www.uscc.gov/sites/default/files/Research/January $\% 202019 \% 20$ Trade $\% 20 \% 2$ OBulletin.pdf.

${ }^{79}$ John VerWey, What's Causing U.S. Semiconductor Equipment Production and Exports to Grow? (Washington, DC: U.S. International Trade Commission, January 2019), 2, https://www.usitc.gov/publications/332/executive_briefings/ebot_john_verwey_semi_m anufacturing equipment pdf.pdf.

${ }^{80}$ As part of the U.S. government's Export Control Reform Initative, military-grade semiconductor technologies were transferred from the U.S. Munitions List to the Commerce Control List in 2014. Edward J. Krauland, Meredith Rathbone, Andrew D. Irwin, Jack R. Hayes, Alexandra E.P. Baj and Henry N. Smith, "Export control reform - military electronics and spacecraft," Lexology, July 16, 2014,

https://www.lexology.com/library/detail.aspx?g=e2053f48-738f-4e7c-8bdd-

$1 \mathrm{~b} 3 \mathrm{dca} 8 \mathrm{~b} 913 \mathrm{~b}$. This change may have reduced the scope of controls, resulting in increased exports. Andrea Stricker with David Albright, "U.S. Export Control Reform: Impacts and Implications for Controlling the Export of Proliferation-Sensitive Goods and Technologies, A Policy Document for the New President and Congress," (Washington, DC: Institute for Science and International Security, May 17, 2017), https://isis-online.org/isisreports/detail/u.s.-export-control-reform-impacts-and-implications/.

${ }^{81}$ Susan N. Houseman and Michael Mandel, Measuring Globalization: Better Trade Statistics for Better Policy (Kalamazoo, MI: W.E. Upjohn Institute, 2015), 81 - 1 18: Kimberly Bayard, David Byrne and Dominic Smith, "Chapter 4: The Scope of U.S. 'Factoryless Manufacturing," https://www.jstor.org/stable/i.ctvh4zfcn.23? seq=1\#metadata_info_tab_contents. ${ }^{82}$ The chips and OSD data includes exports associated with Harmonized Tariff Schedule categories 8541 and 8542 .

${ }^{83}$ The SME data includes exports associated with Harmonized Tariff Schedule categories $8480.71 .4000,8486,8543.70 .2000,8543.90 .1100,9030.82$, and 9031.41 . Fab equipment includes all categories of SME except assembly, testing, and packaging equipment. 
${ }^{84}$ The materials and inputs data includes exports associated with Harmonized Tariff Schedule categories 2804.61.0000, 2825.60.0000, 2849.20.1000, 3701.30.0000, $3701.99 .6030,3701.99 .7000,3707.90 .0000,3818.00 .0000,8112.92 .0600$, and 8112.92 .9000 . Silicon, silicon carbide, gallium arsenide, and germanium are commonly used to produce wafers. Silicon is by far the most common.

${ }^{85} \mathrm{BIS}$ makes an RWA decision when, for example, the license is not required or if more information is needed.

86 "Licensing Analysis," Bureau of Industry and Security.

https://www.bis.doc.gov/index.php/statistical-reports/licensing-analysis. "Country

Analysis," Asia Analysis, Bureau of Industry and Security, https://www.bis.doc.gov/index.php/statistical-reports/country-analysis/asia.

${ }^{87}$ O'Keeffe et al., "New Export Restrictions."

${ }^{88}$ Deemed export applications for Chinese nationals were more popular for semiconductor technical data than for any other type of technical data. Specifically, the ECCN 3EOO 1 was the most commonly approved deemed export license application for Chinese nationals. Bureau of Industry and Security, "Deemed Export Licenses," March 5, 2019, https://www.bis.doc.gov/index.php/documents/technology-evaluation/ote-dataportal/licensing-analysis/2410-2018-statistical-analysis-of-bis-licensing-pdf/file.

${ }^{89} \mathrm{O}$ 'Keeffe et al., "New Export Restrictions."

${ }^{90}$ This dataset includes some irregularities. For example, the number of applicants does not match the application counts in BIS's published reports, suggesting that two datasets count applicants and applications differently. This dataset also includes dollar values, but this report does not present that data due to irregularities such as outlier data points.

${ }^{91}$ United States General Accounting Office, Export Controls: Rapid Advances in China's Semiconductor Industry Underscore Need for Fundamental U.S. Policy Review (Washington, DC: United States Congress, April 2002), 3,

https://www.gao.gov/assets/240/234373.pdf.

${ }^{92}$ All seven applications were categorized under ECCN 3B00 1, which covers "Equipment for the manufacturing of semiconductor devices or materials."

${ }^{93}$ Up to 2015, the Wassenaar Arrangement and the U.S. Commerce Control List listed anisotropic dry etching equipment. In 2015, BIS found that China was producing this equipment. Foreign Availability Determination: Anisotropic Plasma Dry Etching Equipment, 80 Fed. Reg. 6948 (February 9, 2015),

https://www.federalregister.gov/documents/2015/02/09/2015-02681/foreignavailability-determination-anisotropic-plasma-dry-etching-equipment. After this finding, the Wassenaar Arrangement and, effective September 20, 2016, the U.S. Commerce Control List were amended to remove this equipment. Wassenaar Arrangement 2015 Plenary Agreements Implementation, Removal of Foreign National Review Requirements, and Information Security Updates, 81 Fed. Reg. 64,655 (September 20, 2016) (revising 15 CFR $\S 730,734,738,740,742,743,748,770,772$, and 774 . https://www.federalregister.gov/documents/2016/09/20/2016-21544/wassenaararrangement-2015-plenary-agreements-implementation-removal-of-foreign-nationalreview. 
${ }^{94}$ Cheng Ting-Fang, "Chinese chipmaker takes on TSMC and Intel with cutting-edge tool," Nikkei Asian Review, May 15, 2018, https://asia.nikkei.com/Business/Companies/Chinese-chip-maker-invests-in-next-gen-toolto-close-gaps-with-Intel-TSMC-Samsung.

${ }^{95}$ David Manners, "China buys first EUV machine," September 29, 2018, Electronics Weekly, https://www.electronicsweekly.com/news/business/china-buys-first-euvmachine-2018-09/.

${ }^{96}$ Alexandra Alper, Toby Sterling, and Stephen Nellis, "Trump administration pressed Dutch hard to cancel China chip-equipment sale," Reuters, January 6, 2020,

https://www.reuters.com/article/us-asml-holding-usa-china-insight-idUSKBNIZ50HN;

Cheng Ting-Fang and Laury Li, "Exclusive: ASML chip tool delivery to China delayed amid US ire," Nikkei Asian Review, November 6, 2019,

https://asia.nikkei.com/Economy/Trade-war/Exclusive-ASML-chip-tool-delivery-to-Chinadelayed-amid-US-ire. The Chinese government responded that this export ban could damage bilateral relations between China and the Netherlands. Toby Sterling and Anthony Deutsch, "Chinese ambassador warns Dutch government against restricting ASML supplies," Reuters, January 15, 2020, https://www.reuters.com/article/us-netherlands-asml-chinaidUSKBN1ZE1Z8.

9785 Fed. Reg. 23,459.

9885 Fed. Reg. 52,934.

99 Revitalizing Multilateral Export Control Diplomacy for Critical Technologies Act, H.R. 8329, 116 th Cong. (2020). 